\title{
Peran Komunitas Perempuan Pejuang Dalam Mendampingi Kasus Kekerasan Terhadap Anak Di Kelurahan Kurao Pagang, Kecamatan Nanggalo, Kota Padang
}

\author{
${ }^{1}$ Irma Susanti, ${ }^{2}$ Ariesta, ${ }^{3}$ Isnaini \\ 1,2,3Program Studi Pendidikan Sosiologi STKIP PGRI Sumatera Barat \\ e-mail: irmaashusanty@gmail.com
}

\begin{abstract}
The womens Fighting Community is a non-governmental organization assisted by the WCC Nurani Perempuan which is anganged in assisting cases of violonce against children (KTA), cases of domestic violonce (KDRT), and sexual violence (KS). This study aims to describe the role pf the Womens Fighting community cases of violence against children in Kurao Pagang Village, Nanggalo District, Padang City. This study uses Theory of Structural Functionalism. This research is a descriptive qualitative type. The informants of this research were the women fighters community board, the head of the Kurao Pagang Village RT, and the reporters of violence cases. The selection of informants used purposive sampling technique with 8 informants. The types of data used in this study are primary data and secondary data. The data collection methods used were in-depth interviews and document studies. The techniques used in data analysis are data collection, data processing, and descriptive analysis of the data in order to obtain in-depth information about what constitutes research. The result of this study indicate that the types of cases assisted by the Womens Fighters community and the role of the Womens Fighters community in assisting cases of violence against 2018-2019 are 1.) Cases of physical violence. 2.) Cases of physical and sexual violence assisted by the Womens Fighters community. The role of the women combatants in assisting cases of violence againts hildren, namely as a companion to cases of violence, counseling victims, collaborating with other instituons, and providing reinvorcement to victims and victims families.
\end{abstract}

Keyword: Role, Community, Violence

\begin{abstract}
Abstrak
Komunitas Pejuang Perempuan merupakan lembaga swadaya masyarakat binaan WCC Nurani Perempuan yang bergerak dalam pendampingan kasus kekerasan terhadap anak (KTA), kasus kekerasan dalam rumah tangga (KDRT), dan kekerasan seksual (KS). Penelitian ini bertujuan untuk mendeskripsikan peran komunitas Perempuan Pejuang kasus kekerasan terhadap anak di Desa Kurao Pagang Kecamatan Nanggalo Kota Padang. Penelitian ini menggunakan Teori Fungsionalisme Struktural. Jenis penelitian ini adalah deskriptif kualitatif. Informan penelitian ini adalah pengurus komunitas pejuang perempuan, ketua RT Desa Kurao Pagang, dan pelapor kasus kekerasan. Pemilihan informan
\end{abstract}


menggunakan teknik purposive sampling dengan jumlah informan 8 orang. Jenis data yang digunakan dalam penelitian ini adalah data primer dan data sekunder. Metode pengumpulan data yang digunakan adalah wawancara mendalam dan studi dokumen. Teknik-teknik yang digunakan dalam analisis data adalah pengumpulan data, pengolahan data, dan analisis deskriptif data untuk memperoleh informasi yang mendalam tentang apa yang dimaksud dengan penelitian. Hasil penelitian ini menunjukkan bahwa jenis kasus binaan komunitas Pejuang Wanita dan peran komunitas Pejuang Wanita dalam pendampingan kasus kekerasan terhadap 2018-2019 adalah 1.) Kasus kekerasan fisik. 2.) Kasus kekerasan fisik dan seksual binaan komunitas Pejuang Wanita. Peran perempuan kombatan dalam pendampingan kasus kekerasan terhadap anak yaitu sebagai pendamping kasus kekerasan, pendampingan korban, bekerjasama dengan lembaga lain, dan memberikan penguatan kembali kepada korban dan keluarga korban.

\section{Kata Kunci: Peran, Komunitas, Kekerasan}

Anak merupakan seseorang yang belum dewasa yang berusia 0 sampai dengan 18 tahun. Anak merupakan individu yang lemah yang belum mampu memikul beban seperti halnya orang dewasa. Anak membutuhkan perlindungan dan kasih sayang dari orang dewasa.

Anak merupakan anugrah Tuhan Yang Maha ESA, anak juga sebagai generasi muda yang menjanjikan dan merupakan aset negara karena dengan terbentuk generasi muda yang idealis maka bangsa Indonesia akan ikut maju dan berkembang. Anak merupakan generasi muda yang belum mandiri maka anak perlu perlindungan dan pemeliharaan dengan penuh kasih sayang agar mereka merasa aman, nyaman, dan sejahtera. Hal ini dilakukan karena anak merupakan individu yang belum mampu memikul beban dan resiko dari segala perubahan yang dilakukan seperti halnya orang dewasa (Riyanto, 2012)

Secara umum yang dikatakan anak adalah seorang yang dilahirkan dari perkawinan antara seorang perempuan dan laki-laki dengan tidak menyakut bahwa sesseorang yang dilahirkn oleh wanita meskipun tidak pernah melakukan pernikahan tetap dikatakan anak. Menurut John Locke (dalam Gunarsa, 1986), anak adalah pribadi yang masih bersih dan peka terhadap rangsangan-rangsangan yang berasal dari lingkungan.

Selain itu menurut Undang-Undang Republik Indonesia No. 23 Tahun 2002 mengenai Perlindungan Anak, menyebutkan bahwa anak adalah seseorang yang belum berusia 18 tahun, termasuk anak yang masih dalam kandungan. Anak merupakan titipan Allah SWT kepada kedua orang tua, yang harus dijaga dan didik agar menjadi anak yang berguna bagi bangsa dan negara serta menjadi anak sholeh dan sholeha.

Secara teoritis, kekerasan terhadap anak (child abuse) dapat didefenisikan sebagai peristiwa perlakuan fisik, mental, atau seksual yang umumnya dilakukan orangorang yang mempunyai tanggung jawab terhadap kesejahteraan anak yang mana itu semua diindikasi dengan kerugian dan ancaman terhadap kesehatan dan kesejahteraan anak. Child abuse 
sebenarnya tidak hanya berupa pemukulan atau penyerangan secara fisik, melainkan juga bisa berupa berbagai bentuk eksploitasi.

Ada empat macam jenis kekerasan yang sering terjadi kepada anak antara lain. Pertama kekerasan fisik. bentuk ini paling mudah dikenali. Terkategorisasi sebagai kekerasan jenis ini adalah; menampar, menggigit, membenturkan, menendang, memikul/mencekik, mendorong, mengancam dengan benda tajam dan sebagainya. Korban jenis ini biasanya tanpa secara langsung pada fisik korban seperti; luka memar, berdarah, patah tulang, pingsan dan bentuk lain yang kondisinya lebih berat.

Kedua kekerasan psikis. Kekerasan jenis ini tidak begitu mudah dikenali. Akibat yang dirasakan oleh korban tidak memberikan bekas yang jelas bagi orang lain. Dampak kekerasan jenis ini akan berpengaruh pada situasi perasaan tidak aman dan nyaman, menurunya harga diri serta martabat korban. wujud konkret kekerasan atau pelanggaran jenis ini adalah; penggunaan kata-kata kasar, penyalahgunaan kepercayaan, mempermalukan orang lain di depan orang lain atau di depan umum, melontarkan ancaman dengan kata-kata, dan sebagainya. Akibat adanya prilaku tersebut biasanya korban akan merasa rendah diri atau kehilangan kepercayaan, minder, merasa tidak beharga, dan lemah dalam membuat keputusan (desicion making).

Ketiga jenis kekerasan seksual. Termasuk dalam kategori ini adalah segala tindakan yang muncul dalam bentuk paksaan atau mengancam untuk melakukan hubungan seksual (sexual intercourse), melakukan penyiksaan atau bertindak sadis serta meninggalkan seseorang termasuk mereka yang tergolong masih berusia anak-anak setelah melakukan hubungan seksualitas. Segala perilaku yang mengarah pada tindakan pelecehan seksual terhada anakanak, baik disekolah di dalam lingkungan sekitar tempat tinggal anak juga termasuk dalam kategori kekerasan atau pelanggaran terhadap hak anak jenis ini. Kasus pemerkosaan anak dan lainnya.

Keempat jenis kekerasan ekonomi. Kekerasan jenis ini sering terjadi di lingkungan keluarga. Pada anak-anak, kekerasan jenis ini sering terjadi ketika orang tua memaksa anak yang masih berusia dibawah umur untuk dapat memberikan kontribusi ekonomi keluarga, sehingga fenomena penjual koran, pengamen jalan, pengemis anak dan lainlain kian merambat di perkotaan (Suyanto, 2003)

Anak yang rentan mendapatkan kekerasan yaitu, pertama anak sangat mudah terpengaruh dengan iming-iming yang diberikan pelaku, kedua anak tidak bisa mengekspresikan apa yang sedang dialaminya dengan bahasa verbal, iga anak mengantungkan hidupnya pada pelaku, keempat lambatnya korban melaporkan kekerasan yang dialami kepada kepolisian atau pihak lain, karena anak tidak mempunyai kekuatan untuk melawan karena pada dasarnya anak manusia yang lemah yang belum mampu memikul beban seperti halnya orang dewasa.

Berkaitan dengan kasus-kasus kekerasan terhadap anak, terdapat lembaga yang memberikan perhatian khusus terhadap masalah tersebut baik lembaga pemerintahan dan non-pemerintahan. Salah satunya adalah WCC Nurani Perempuan yang mempunyai 7 komunitas 
binaan salah satunya komunitas Perempuan Pejuang. Upaya pemerintah

melalui komisi Perlindungan Anak Indonesia dalam melakukan pendampingan kasusu kekerasan terhadap anak dengan mengeluarkan kebijakan Undang-Undang No 23 Tahun 2002 tentang Perlindungan Anak dalam rangka meningkatkan efektifitas penyelenggaraan perlindungan anak.

Anggota komunitas Perempuan Pejuang bekerja secara sukarela. Anggota komunitas ini disebut sebagai relawan, yang tujuannya untuk membantu korban kekerasan serta membekai para anggotanya dengan berbagai keterampilan para anggota ini merupakan tempat atau kawannya dari korban kekerasan. karena anggota komunitas ini merasa mempunyai kewajiban untuk membantu para korban kekerasan, para anggota komunitas mengatakan setidaknya mereka tahu cara mendampingi korban kekerasan, jika saja nantinya salah satu dari keluarga mereka yang mendapatkan kekerasan jadi mereka tahu apa yang harus dilakukan, agar korban kekerasan mendapatkan keadilan dan ada yang memperjuangkan hak-haknya (Profil komunitas Perempuan Pejuang)

Berdasarkan hasil wawancara awal penulis di komunitas Perempuan Pejuang, penulis mendapatkan informasi data kekerasan terhadap anak sebagai berikut:

\begin{tabular}{|c|c|c|c|c|c|c|c|}
\hline No & Nama & Umur & $\mathbf{P} / \mathbf{L}$ & $\begin{array}{l}\text { Jenis } \\
\text { Kekerasan }\end{array}$ & Pelaku & $\begin{array}{l}\text { Alamat } \\
\text { Korban }\end{array}$ & Keterangan \\
\hline 1. & PU & $\begin{array}{l}17 \\
\text { tahun }\end{array}$ & $\mathrm{P}$ & $\begin{array}{l}\text { Kekerasan } \\
\text { fisik dan } \\
\text { seksual }\end{array}$ & $\begin{array}{l}\text { Ayah } \\
\text { tiri }\end{array}$ & $\begin{array}{l}\text { RT 05, RW } \\
03 \\
\text { Kelurahan } \\
\text { Kurao } \\
\text { Pagang }\end{array}$ & $\begin{array}{l}\text { Kasus terhenti } \\
\text { karena orang tua } \\
\text { dari korban } \\
\text { meninggal dunia }\end{array}$ \\
\hline 2. & SA & $\begin{array}{l}11 \\
\text { tahun }\end{array}$ & $\mathrm{P}$ & $\begin{array}{l}\text { Kekerasan } \\
\text { seksual dan } \\
\text { fisik }\end{array}$ & Kerabat & $\begin{array}{l}\text { Kelurahan } \\
\text { Kurao } \\
\text { Pagang }\end{array}$ & $\begin{array}{l}\text { Kasus terhenti } \\
\text { karena korban } \\
\text { meninggal dunia }\end{array}$ \\
\hline 3. & LA & $\begin{array}{l}11 \\
\text { tahun }\end{array}$ & $\mathrm{P}$ & $\begin{array}{l}\text { Kekerasan } \\
\text { fisik }\end{array}$ & $\begin{array}{l}\text { Ayah } \\
\text { tiri }\end{array}$ & $\begin{array}{l}\text { Pesisir } \\
\text { selatan }\end{array}$ & $\begin{array}{l}\text { Kasus terhenti } \\
\text { karena korban } \\
\text { dijemput paksa } \\
\text { orang tua }\end{array}$ \\
\hline 4. & IB & $\begin{array}{l}12 \\
\text { tahun }\end{array}$ & $\mathrm{L}$ & $\begin{array}{l}\text { Kekerasan } \\
\text { seksual } \\
\text { (kasus } \\
\text { sodomi) }\end{array}$ & $\begin{array}{l}\text { Orang } \\
\text { luar }\end{array}$ & $\begin{array}{l}\text { Jln. Khatib } \\
\text { Sulaiman. } \\
\text { Padang } \\
\text { Utara }\end{array}$ & $\begin{array}{l}\text { Kasus terhenti } \\
\text { karena korbar } \\
\text { pergi merantau }\end{array}$ \\
\hline
\end{tabular}

Sumber: Buku kasus komunitas Perempuan Pejuang. Tahun 2018-2019

Berdasarkan tabel 1.1 menjelaskan bahwa anak yang mendapatkan kekerasan yaitu anak yang tidak tinggal dengan orang tua kandungnya dan yang tinggal dengan keluarga jauhnya. Dari data tersebut dapat disimpulkan jenis kekerasan yang sering 
menimpa anak adalah kekerasan seksual dan kekerasan. Pelaku kekerasan terhadap anak adalah orang-orang terdekat seperti ayah tiri, sepupu dan orang yang berada dilingkungan sekitarnya. Anak yang rentan mendapatkan kekerasan adalah anak yang mudah diiming-imingi dengan hadiah atau benda yang menjadi kesukaanya, dari sinilah pelaku melakukan aksinya, berdasarkan wawancara awal anak diajak oleh pelaku untuk jalan-jalan, pada saat anak sudah merasa dekat pelaku leluasa untuk melakukan kekerasan kepada anak.

Kegiatan komunitas Perempuan Pejuang dari tahun 2018-2019 sudah mendampingi beberapa kasus seperti kasus kekerasan dalam rumah tangga (KDRT), kekerasan terhadap anak (KTA) dan kekerasan seksual (KS).

Berdasarkan latar belakang diatas maka yang menjadi rumusan masalaah dalam penelitian ini adalah:

1. Bagaimana jenis-jenis kekerasan yang didampingi komunitas Perempuan Pejuang?

2. Bagaimana peran komunitas Perempuan Pejuang dalam mendampingi kasus kekerasan terhadap anak?

\section{METODE PENELITIAN}

Penelitian ini menggunakan menggunakan penelitian kualitatif dengan tipe deskriptif. Penelitian kualitatif adalah metode penelitian ilmu-ilmu sosial yang mengumpulkan dan menganalisis data berupa kata-kata (lisa aupun tulisan) dan perbuatan-perbuatan manusia serta peneeliti tidak berusaha menghitung atau mengkuantifikasikan data kualitatif yang telah diperoleh dan dengan demikian tidak menganalisis angka-angka(Afrizal, 2014). Peneliti menggunakan metode kualitatif dengan berbagai alasan: Pertama, karena metode penelitian kualitatif berguna untuk mengungkapkan proses kejadian secara mendetail, sehingga diketahui dinamika sebuah realitas sosial dan saling pengaruh berbagai realitas sosial, hal ini dapat menginformasikan peran komunitas Perempuan Pejuang dalam mendampingi kasus kekerasan terhadap anak. Kedua, esensi data yang akan dikumpulkan dan analisis, alasannya karena penulis perlu menumpulkan data dan analisis berupa kata-kata dan perbuatan manusia yaitu peran dari komunitas Perempuan Pejuang. Ketiga supaya peneliti dapat mengungkapkan permasalahan secara mendalam serta mendapatkan informasi yang sebanyak-banyaknya melalui wawancara dan studi dokumen.

Tipe penelitian yang digunakan dalam penelitian ini adalah penelitian deskriptif merupakan penelitian yang berusaha mendeskripsikan suatu gejala, peristiwa, kejadian yang terjadi saat sekarang (Noor, 2011). Teknik pemilihan informan menggunakan purposive sampling berdasarkan atas anggapan bahwa informan adalah orang yang benar-benar mengetahui, memiliki keterkaitan dengan permasalahan yang dan objek penelitian (Arikunto, 2006)

Jenis data dalam penelitian adalah data primer dan data sekunder. Data primer peneliti dapatkan dari hasil wawancara dengan pengurus komunitas Perempuan Pejuang, pelapor atau keluarga korban dan ketua RT Kelurahan Kurao Pagang. Unit analisis penelitian ini adalah kelompok komunitas Perempuan Pejuang di Kelurahan Kurao Pagang, Kecamatan Nanggalo, Kota Padang. Langkah-langkah dalam menganalisis data adalah pengumpulan data, reduksi data, display data (penyajian data) dan penarikan kesimpulan atau verifikasi data.

\section{HASIL DAN PEMBAHASAN}

\section{Kasus yang Didampingi Komunitas Perempuan Pejuang}

Komunitas Perempuan Pejuang merupakan sebuah Lembaga Swadaya Masyarakat yang berdiri di Kelurahan Kurao Pagang, 
Kecamatan Nanggalo, Kota Padang. Dimana komunitas ini mempunyai program seperti diskusi reguler (setiap bulan), kegiatan lintas komunitas/organisasi serta mendampingi kasus kekerasan. anggota yang tergabung dalam komunitas ini merupakan ibu-ibu rumah tangga, tetapi mereka mendapatkan pelatihan dari WCC Nurani Perempuan ataupun lembaga lainnya, para ibu-ibu tersebut dilatih dan diajarkan tentang langkah-langkah dalam mendampingi kasus kekerasan.

komunitas Perempuan Pejuang melakukan tugas dan fungsinya sesuai dengan keinginan atau kebutuhan korban dalam mendampingi kasus kekerasan dengan adanya korban atau keluarga korban meminta bantuan kepada pihak komunitas untuk mendampingi kasus yang menimpanya. Komunitas Perempuan Pejuang pernah mendampingi kasus kekerasan seksual dan fisik. yang tergolong dalam kasus kekerasan seksual yang pernah didampingi komunitas adalah kasus sodomi. Saat mendampingi kasus kekerasan pihak komunitas memberikan pelaayanan sesuai dengan kebutuhan korban, misalnya kasus sodomi yang menimpa IB.

Pihak komunitas mendampingi korban sampai kepada pihak kepolisian, selanjutnya kasus kekerasan fisik yang menimpa LA pihak komunitas juga mendampingi korban sampai dengan membawa korban ke rumah sakit, dan kasus kekerasan seksual dan fisik yang menimpa PU dan SA pihak komunitas juga melakukan pendampingan dengan melaporkan kejadian tersebut ke pihak kepolisian dan membawa korban ke rumah sakit serta memberikan konseling kepada korban dan keluarga korban.

\section{Kasus Kekerasan Fisik}

Kekerasan fisik terhadap anak merupakan kekerasan yang kemungkinan besar terjadi. Termasuk dalam kekerasan fisik adalah ketika seseorang menggunakan anggota tubuhnya atau obyek yang bisa membahayakan seseorang anak atau mengontrol kegiatan atau tindakan anak.

Kasus kekerasan fisik yang menimpa seorang anak perempuan yang berinisial LA yang berusia 10 tahun. LA mendapatkan kekerasan fisik dari ayah tirinya aksi ini dilakukan saat ibu kandung dari LA tidak berada di rumah. Dampak yang dirasakan korban dari kasus kekerasan tersebut adalah korban mengalami ketakutan dan trauma, trauma dengan orang yang belum dikenalnya korban sering merasa kesakitan disekitar tubuhnya. Korban membutuhkan perlindungan dan penguatan mental. Tetapi pada saat proses pendampingan berlanjut ibu kandung korban menjemput paksa sehingga kasus ini harus terhenti.

Kendala yang dihadapi komunitas Perempuan Pejuang saat mendampingi kasus tersebut seperti kurangnya dukungan dari pihak keluarga, contohnya saat mendampingi kasus LA, ibu kandung dari korban menjemput paksanya sehingga kasus ini harus terhenti.

\section{Kasus Kekerasan Fisik dan Seksual}

Kasus kekerasan fisik dan seksual yang pernah didampingi oleh komunitas Perempuan Pejuang adalah sebagai berikut:

Sodomi adalah istilah hukum yang digunakan untuk merujuk kepada tindakan seks "tidak alami" yang tergantung pada yuridiksinya dapat terdiri atas seks oral, seks anal atau semua bentuk pertemuan organ non- kelamin dengan alat kelamin, baik dilakukan secara heteroseksual. Kasus sodomi yang menimpa anak laki-laki yang berinisial IB yang berumur 12 tahun. IB mendapatkan kasus sodomi dari orang yang tidak kenalnya atau orang luar.

Komunitas Perempuan Pejuang melakukan pendampingan dengan cara sebagai berikut:

(1.) Pihak komunitas mendatangi IB ke sekolahnya dan menjalin kedekatan atau raporrt dengan korban 
tujuannya agar korban lebih terbuka dalam menceritakan permasalahannya. Pihak komunitas menjadi kawan bicara bagi korban mendengarkan semua cerita korban. setelah mendengarkan cerita dari IB pihak komunitas pun langsung mengajak IB ke tempat ia dilecehkan oleh preman tersebut.

(2.) Pihak komunitas megajak IB ke tempat ia mendapatkan kekerasan dengan menggunakan jasa Gocar yang dibiayai oleh anggota komunitas.

(3.) Pihak komunitas melakukan outreach atau penjangkauan keluar yaitu kapolsek Nanggalo dan kepolisian meminta wali untuk kasus ini agar ditindak lanjuti.

(4.) Pihak komunitas memberikan motivasi dorongan kepadanya dengan tujuan agar IB bisa melupakan kejadian tersebut dan kembali seperti biasa.

Kendala yang dihadapi komunitas Perempuan Pejuang saat mendampingi kasus sodomi seperti sikap yang dimiliki oleh keluarga korban. Saat mendampingi kasus IB pihak komunitas susah mencari wali untuk IB, karena pada saat melaporkan kejadian tersebut kepada pihak kepolisian maka kepolisian akan meminta wali dengan tujuan agar nantinya tidak ada pihak yang menuntut.

Kasus kekerasan fisik dan seksual yang menimpa seorang anak perempuan yang berinisial SA yang berumur 11 tahun dan seorang remaja perempuan yang berinisial PU yang berumur 17 tahun. Berikut ini adalah uraian kasus kekerasan fisik dan seksual.

a. Kasus kekerasan seksual, fisik dan psikis yang menimpa SA yang berumur 11 tahun. Ia mendapatkan kekerasan dari kerabatnya sendiri. Pihak komunitas yang mendapatkan laporan segera melakukan pendampingan dengan cara sebagaai berikut:
(1.) Pihak komunitas ikut serta ke puskemas ditolak dan dirujuk ke rumah sakit Ibnu Sina dan dirujuk ke M. Djamil kemudian dirujuk kembali ke rumah sakit Bhayangkara. Dan dirumah sakit inilah SA mendapatkan pertolongan.

(2.) Pihak komunitas yang ikut dalam mendampingi ke rumah sakit berusaha menenangkan orang tua dari korban yang menangis melihat keadaan anaknya.

(3.) Kasus ini dirujuk kepada WCC Nurani Perempuan dan akhirnya diteruskan pada LBH.

(4.) Pihak komunitas ikut serta dalam pemakaman korban. Dampak yang terjadi pada korban yaitu korban meninggal dunia.

b. Kasus kekerasan fisik dan seksual yang menimpa PU remaja yang berusia 17 tahun. PU mendapatkan kekerasan fisik dan seksual dari ayah tirinya.

Proses penyelesaian kasus kekerasan yang dilakukan komunitas bermacam-macam mulai dari terlebih dahulu menyarankan untuk menyelesaiakan masalah secara kekeluargaan sampai dengan membawa kasus tersebut ke pihak kepolisian.

\section{Peran Komunitas Perempuan Pejuang}

Peran merupakan aspek dinamis kedudukan (status), apabila seseorang melaksanakan hak dan kewajibannya sesuai dengan kedudukannya, maka ia menjalankan suatu peran.

Peran dari komunitas Perempuan Pejuang dalam mendampingi kasus kekerasan terhadap anak adalah setiap korban yang melapor kepada komunitas, komunitas berusaha mencari jalan keluar dari masalah atau berusaha menyelesaikan masalah tersebut, terlebih dahulu anggota komunitas melakukan pendekatan kepada korban agar korban merasa lega dan tidak gugup untuk menceritakan apa yang terjadi kepada dirinya, pada saat bercerita tentang masalah 
yang menimpanya peran anggota komunitas berusaha mendengarkan keluh kesah korban, disini para anggota komunitas berperan sebagai pendengar yang baik untuk mendengarkan cerita korban.

Komunitas Perempuan Pejuang mempunyai beberapa peran saat mendampingi kasus kekerasan, adapun peran dari komunitas Perempuan Pejuang adalah sebagai berikut:

\section{Pendampingan Kasus Kekerasan}

Pendampingan adalah suatu proses hubungan sosial antara pendamping dengan korban dalam bentuk pemberian kemudahan untuk memecahkan suatu masalah. Di komunitas Perempuan Pejuang proses pendampingan korban dilakukan oleh relawan yang telah mendapati pelatihan dari WCC Nurani Perempuan ataupun lembaga lainnya. Orang yang mendampingi disebut dengan pendamping.

Pendampingan dilakukan komunitas Perempuan Pejuang kepada korban kekerasan sampai yang diinginkan oleh korban ataupun keluarga korban. Komunitas Perempuan Pejuang menjaga kerahasian, karena kasus kekerasan merupakan kasus yang sensitif dan rentan terhadap penyalahgunaan informasi.

Komunitas Perempuan Pejuang melakukan pendampingan kepada korban kasus kekerasan sesuai dengan kebutuhan korban. jika korban mengalami luka-luka maka pihak komunitas akan membawa ke rumah sakit, selain itu pihak komunitas juga melakukan penjangkauan keluar. Pada program pendampingan, pendamping bertugas membantu korban sehingga korban dapat memperoleh akses terhadap berbagai sumber untuk mempercepat keberhasilan usahanya, memberikan bantuan pertolongan pada korban dalam rangka menghadapi permasalahan yang dihadapinya.

\section{Konseling Kepada Korban}

Konseling merupakan upaya seseorang untuk membantu individu lain melalui interaksi yang bersifat pribadi sehingga akan mampu membuat suatu keputusan terbaik. Konseling dilakukan dengan tujuan membantu menyelesaikan permasalahan yang sedang dihadapi oleh orang lain. Komunitas Perempuan Pejuang mempunyai peran sebagai konseling yang mendapatkan pelatihan dari WCC Nurani Perempuan atau lembaga lainnya. Orang yang memberikan konseling atau disebut dengan konselor terlebih dahulu mendekati korban dengan tujuannya untuk menumbuhkan rasa percaya korban kepada konselor dengan cara menciptakan kepercayaan kepada konselor.

Komunitas Perempuan Pejuang melakukan konseling kepada korban dan keluarga korban yang tujuannya agar korban tersebut mengalami perubahan pada psikologisnya, setelah dilakukannya konseling diharapkan psikologis korban dapat stabil kembali atau lebih baik.

\section{Melakukan Kerjasama dengan Lembaga Lain}

Komunitas Perempuan Pejuang melakukan kerjasama dengan lembaga lain atau dalam bahasa lain outreach merupakan penjangkauan keluar. Dalam hal ini, penjangkauan keluar dilakukan terhadap korban yang belum memperoleh pendampingan baik dari lembaga lainnya maupun pihak hukum. Dalam hal ini, pratikan outreach terhadap kasus kekerasan seksual. Dari kasus yang didampingi oleh komunitas Perempuan Pejuang yang pernah melakukan kerja sama dengan lembag lain ketika mendampingi IB.

Komunitas Perempuan Pejuang juga melakukan kerjasama dengan lembaga lain seperti pihak kepolisian. Dalam melakukan penjangkauan keluar kadang kala pihak komunitas kesulitan mencari wali bagi korban karena jika melaporkan kejadian tersebut kepada pihak kepolisian maka akan diminta walinya. Tujuan dari komunitas 
untuk melakukan penjangkauan keluar untuk mempermudah penyelesaian kasus kekerasan tersebut. Agar korban kekerasan mendapatkan hak-haknya.

\section{Memberikan Penguatan Kepada Korban dan Keluarga Korban}

Penguatan adalah segala bentuk respon positif yang diberikan kepada korban dan keluarga korbankekerasan. Penguatan yang diberikan komunitas berupa motivasi. Pendamping berperan memberikan rangsangan dan dorongan semangat kepada korban maupun keluarga korban untuk bersikap positif, sehingga dapat mengembangkan potensi yang dimilikinya. Komunitas Perempuan Pejuang memberikan penguatan kepada korban kasus kekerasan dengan cara memberikan dukungan serta kata-kata yang membuat semangat korban kembali percaya diri.

Biasanya jenis penguatan yang diberikan komunitas kepada korban maupun keluarga korban berupa penguatan verbal yang diungkapkan dengan kata-kata. Tujuan dari penguatan kepada korban dan keluarga korban diharapkan dengan semua itu bisa membuat semangat dan percaya dirinya kembali. Serta melanjutkan kehidupannya mengembangkan potensi-potensi yang dimilikinyadan menjadikan itu semua pelajaran agar kita selalu waspada dan meningkatkan pengawasan dan penjagaan kepada anggota keluarga serta meningkatkan keimanan kepada Tuhan Yang Maha ESA.

\section{SIMPULAN}

Berdasarkan hasil penelitian dan wawancara bersama informan mengenai peran komunitas Perempuan Pejuang dalam mendampingi kasus kekerasan terhadap anak, di Kelurahan Kurao Pagang, Kecamatan Nanggalo, Kota Padang. Bahwa komunitas Perempuan Pejuang adalah sebuah Lembaga Swadaya Masyarakat yang bergerak dalam mendampingi kasus kekerasan. komunitas Perempuan Pejuang tidak hanya mendampingi kasus kekerasan tetapi juga mempunyai program yang tujuannya untuk meningkatkan perekonomian masyarakat sekitarnya.

Peran dari komunitas Perempuan Pejuang adalah sebagai pendamping kasus kekerasan, konseling kepada korban, melakukan kerjasama dengan lembaga lain dan memberikan penguatan kepada korban dan keluarga korban. Jenis kasus yang pernah didampingi komunitas adalah kasus kekerasan fisik dan seksual. Komunitas Perempuan Pejuang melakukan pendampingan sesuai dengan kebutuhan korban. anak yang rentan mendapatkan kekerasan adalah anak yang tidak tinggal dengan orang tua kandungnya. Anak di anggap makhluk lemah yang mudah diiming-imingi dengan uang ataupun benda yang menjadi kesukaanya.

\section{SARAN}

Berdasarkan hasil penelitian di atas maka peneliti memberikan saran kepada:

\section{Orang tua}

Setelah dilakukannya penelitian ini diharapkan orang tua lebih meningkatkan cara pengawasannya kepada anak-anaknya. Kadang kala kekerasan itu datang dari pihak yang terdekat. Orang tua diharapkan lebih waspada dalam menjaga anaknya, dan meningkatkan keimanan dan ketaqwaan kita kepada Tuhan Yang Maha ESA. Karena anak merupakan titipah sang pencipta yang harus dijaga dan mendapatkan kasih sayang dari orang-orang sekililingnya.

\section{Komunitas Perempuan Pejuang}

Setelah dilakukan penelitian ini semoga komunitas Perempuan Pejuang semakin jaya dan maju, jika ada korban kekerasan maka ia mempunyai tempat untuk melaporkan kejadian dan mendapatkan hak-haknya di depan hukum. 
SUMBER RUJUKAN

\section{Buku}

Afrizal. (2014). Metodologi Penelitian Kualitatif. Bandung. Bandung: Remaja Rosdakarya.

Bungin. (2001a). Metodologi Penelitian Sosial. Surabaya: Perss.

Bungin, B. (2001b). Metodologi Penelitian Sosial. Surabaya: Airlangga University Press.

Moleong. (2010). Metodologi Penelitian

Kualitatif. Bandung. Bandung: Remaja Rosdakarya.

Prof. Dr. Djaman Sotari, D. (2010). Metodologi Penelitian Kualitatif. Bandung. Bandung: Alfabeta.

Riyanto, A. (2012). Sosiologi Hukum,

Kajian Hukum Secara Sosiologis (Yayasan Pu). Jakarta.

Soekanto, S. (1987). Sosiologi Hukum Dalam Masyarakat. Jakarta. Rajawali. Suyanto, B. (2003). Masalah Sosial Anak. Jakarta: Prenada Media Group.

Arikunto, S. (2006).Prosedur Penelitian Suatu Pendekatan Pratek. Jakarta: Rineka Cipta

Suyanto, B. (2010). Masalah Sosial Anak. Jakarta: Fajar Interpratama Mandiri

Ritzer, G. (2004). Teori Sosiologi Modern. (P. K. P. M. Group, ED). Jakarta

\section{Jurnal}

Kusumawati, Sella. Peran Pusat Pelayanan Terpadu Perempuan Dan Anak Dalam Pendampingan Anak-Anak Korban Kekerasan Seksual Bermasalah Sosial Di Kabupaten Wonogiri.

Prima, Nia Shartika. Analisis Penyelenggaraan Puskesmas Tata Laksana Kekerasan Terhadap Anak (KTA) Dalam Penanganan Kekerasan Anak Di Kota Padang.

Puwaningrum, Juli. (2017). Analisa Sodomi Anak. Proseding Pertemuan Ilmiah

\section{Skripsi}

Latifah, Ila. (2014). Motif Lansia Menyikapi Kegiatan Baca Tulis Di Komunitas Tanah Ombak Padang. Skripsi Stkip.

Zetria, Maisari Yeni. (2013). Fenomena Penggunaan Kamera Profesional Bagi Peserta Didik Di SMAN 5 Pariaman. Skripsi STKIP.

Putri, Eti Siska. (2013). Konflik Gadai Tanah Ulayat (Studi: Pada Masyarakat Yang Melakukan Pratek Pagang-Gadai Tanah Ulayat Kaum Di Jorong Nagari Ladang Panjang Kecematan Tigo Nagari Kabupaten Pasaman). Skripsi STKIP.

Eminurlita. (2014). Dampak Kekerasan Orang Tua Terhadap Anak (Studi Kasus:Di Daerah Lubuk Buaya Koto Tangah Padang). Skripsi STKIP.

Oktavia, Nola. (2014). Strategi LSM Nurani Perempuan Pada Pendanpingan Korban Tindak Kekerasan Dalam Berpacaran Di Kota Padang. Skripsi STKIP.

Ibnu, Ronaldo Awam. (2019). Peran

Dinas Pemberdayaan Perempuan Dan Perlindungan Anak Provinsi Lampung Dalam Penanganan Kasus Kekerasan Terhadap Anak Di Bawah Umur. Skripsi Universitas Lampung.

\section{Peraturan Mentri}

Undang-Undang Nomor. 23 Tahun. 2002. Tentang Perlindungan Anak Undang-Undang Nomor. 39 Tahun. 1999. Tentang Hak Asasi Manusia 